Article

\title{
Elicitive Conflict Transformation and New Media: In Search for a Common Ground
}

\author{
Wolfgang Sützl \\ School of Media Arts and Studies, Ohio University, Athens, OH 45701, USA; E-Mail: suetzl@ohio.edu \\ Submitted: 4 May 2015 | Accepted: 3 November 2015 | Published: 18 February 2016
}

\begin{abstract}
Advocates of elicitive conflict transformation (ECT) maintain that the parties to a conflict are the most important resource in efforts to render that conflict less violent. According to them, the transformation of the conflict is immanent to the conflict itself. The claim of ECT theorists is that classical conflict resolution has mostly aimed at overcoming a conflict by means of neutral mediation, while conflict transformation is not primarily concerned with terminating a conflict and considers the conflict worker as part of the conflict system. Although ECT is a communication-based model of conflict management and relies on human media, its media-theoretical aspects are not made explicit, raising the question of what role technological media play in the communicative processes that make up ECT techniques. Through an examination of the claimed differences between conflict resolution and conflict transformation, and focusing on the common roots of new media and the elicitive model in systems and cybernetic theory, this paper asks whether any peacebuilding potential of new media could be found in a specific anti-propagandistic quality of distributed technological media. It concludes by looking at any such potential in social media.
\end{abstract}

\section{Keywords}

conflict resolution; elicitive conflict transformation; new media theory; peace media; peacebuilding

\section{Issue}

This article is part of the issue "Peacebuilding in the Age of New Media", edited by Vladimir Bratic (Hollins University, USA).

(C) 2016 by the author; licensee Cogitatio (Lisbon, Portugal). This article is licensed under a Creative Commons Attribution 4.0 International License (CC BY).

\section{Introduction}

The purpose of this essay is to contribute towards an understanding of new media in peacebuilding by positing them in the context of recent developments in conflict theory. Specifically, I will examine a shift from the concept of conflict resolution to one of conflict transformation, and its implications in terms of how we understand media and any function they can have within peacebuilding. To this end, I will examine any media-theoretical aspects of elicitive conflict transformation and seek to arrive at conclusions regarding the role of new media in peacebuilding.

I feel justified in doing so because both conflict resolution and transformation imply a mediating agency, some "in-between" space that separates and connects the conflict parties, and where conflict resolution professionals or peace workers operate. The way this inbetween space is conceptualized is significant in theo- rizing and practicing the resolution or transformation of conflicts. I am not going to discuss theories that deny the possibility of a third party to a conflict, as for example those advocated by the Carl Schmitt and Ernst Jünger, although their 'Heraclitan' thinking has a continuing currency (Sützl, 2008). According to those theories, a conflict ends with the victory of one party over the other. However, in as much as they contain a critique of liberalism, they will be relevant at the end of this paper, where my discussion of the peacebuilding potential of social media relies on its distinction between liberalism and peace that has informed recent research on peace and war. This distinction acknowledges the potential for violence inherent in the present global liberal governance (Dillon \& Reid, 2000), the emergence of a distinct form of liberal war (Dillon \& Reid, 2009; Evans, 2011) as well as post-liberal peace (Richmond, 2011).

For the purposes of this essay, I will base my reaso- 
ning on the assumed existence of such a third space between conflict parties. This space is the space of communication, where commonality can become manifest. As such, it is both the space of mediation and

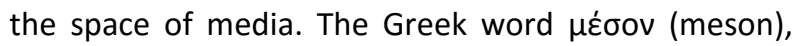
from which the English word 'medium' is derived, does not only refer to the middle; it also stands for the common ground and the common good, thus comprising both the political and the technical aspects of the communication that takes place in order to resolve or transform a conflict.

The second reason why I feel justified in taking this approach, which is that there is an apparent lack of research that looks at conflict resolution or conflict transformation from a media-theoretical angle, with the underlying assumption frequently being the communication occurring in resolving or transforming conflicts is face-to-face, as in the classic setting of the negotiating table. Mediation is understood in terms of a person being 'in the middle,' rather than in terms of a human or technological medium, requiring no specific media-theoretical approach (Curle, 2015) and limiting itself to communication theory (Burton, 2015). Yet the negotiating table is only part of a much larger communication environment in which many different types of media may be present, including technological ones. A theory of conflict resolution or transformation will therefore need to include a media theory. While a small amount of research has been conducted into the role of media in conflict resolution (e.g. Gilboa, 2010, Saleem \& Hanan, 2014), such research has not advanced to the point where a media-theoretical enquiry is engaged.

\section{The Lack of Media Theory in Conflict Resolution Theories}

I suggest three possible explanations of this lack of media theory. Perhaps most obvious among them is that what Friedrich Kittler calls the 'technological media' have a long history of complicity with war: many key media technologies were developed and used for military communications, from the optical telegraphs of antiquity to the missile-guidance systems of the present, from computer technology to internet and satellite communication. It would be hard to deny that the war and the military at least hat a very significant impact on the evolution of the technological media. As is known, Friedrich Kittler went as far as to argue that all technological media have their origin in military purposes and have served war, propaganda and surveillance ever since they existed. Indeed, it would be hard to not see the continuity of war in media history, from the optical telegraphs of antiquity to current concepts of information war or cyberwar (e.g. Eurich, 1995; Snow, 2003; Stocker \& Schöpf, 1998; Virlio, 1989). More recently, the rise of security as a guiding principle of international politics after $9 / 11$ has added to these sus- picions, with critics interpreting security as a technologically driven pursuit of peace that reads pluralism and creativity as potential risks to be politically neutralized (Cox \& Sützl, 2009; Sützl, 2008, 2009).

Such interpretations of the relationship between technological media and peace rest on the assumption that these media do in fact have an impact on what can be communicated, and consequently on the success of conflict transformation. Accordingly, they are not neutral, and that this lack of neutrality makes them unsuitable for mediation in a conflict, or for a peaceoriented political process. Another way of interpreting the apparent absence of a theory of technological media in conflict resolution and conflict transformation theories would be to assume that technological media are neutral, and therefore not in need of theoretical attention. From this perspective, instead of being detrimental to building peace, they would simply be irrelevant. Whether communication occurs face-to-face or through using technological media would have no effect on what is communicated, and consequently on the outcome of the conflict transformation process. This would be a continuation of a long-standing tradition in western philosophy and originating in Platonic thought, according to which knowledge is not affected by the media through which it is communicated, archived, or processed. Kittler becomes a media theorist because Foucault's discourse analysis does not entirely shake off this tradition: lacking a media theory, "his analyses end up immediately before that point in time at which other media penetrated the library's stacks" (Kittler, quoted in Winthrop-Young, 2011, p. 59).

A third explanation might be that there are no adequate theoretical sources that would allow it to form a positive understanding of the relationship between media, peace, and war. Although peace journalism has established itself as a practice and theory following the recognition of the complicated role of journalists in war (e.g. Keeble, Tulloch, \& Zollmann, 2010; Lynch \& McGoldrick, 2005), it has not yet developed its own media theory. In part, this is certainly due to the difficulty of conceptualizing peace, as opposed to violence and war. Peace was long defined in negative terms, as the absence of war, with the advantage of universality, but impossible to represent in positive forms, and therefore of limited use in peacebuilding efforts. Peace researchers in the 1980 s were therefore driven by an ambition, originating in the work of Johan Galtung and others, to develop theories of positive peace that would in fact be helpful in making peace a positive social reality (Galtung, 1964). Yet positive attributes turned out to be much more problematic to generalize than negative ones, as they are inseparable from cultural values which, if universalized, might generate their own cultural violence (Galtung, 1990). The response to this dilemma consisted in a pluralization of peace theories, either in the form of considering peace as cultural- 
ly contingent and speaking of 'peaces' instead of one peace (Dietrich, 2011, 2012), or in a turn towards conflict resolution, with the meaning of positive peace being contingent upon the conflict constellation and parties.

The following enquiry into peace media, and the status of technological media in ECT is an attempt to contribute to the theoretical resources that will allow an understanding of the relationship between media and peace.

\section{Bratić's Peace Media Theory}

Is it possible to view technological media as capable of promoting peace? In a study of media in post-conflict peacebuilding settings, Bratić (2008) starts with the affirmation that "cases of the positive use of mass communication channels in the reconciliation of postconflict societies" are "virtually unknown"(p. 487) and he proposes the term "peace media" for media created by non-conflict parties for the purpose of actively supporting a post-conflict peacebuilding effort by transforming the cultural violence (as defined by Galtung, 1990) that inevitably exists in every violent situation. Indeed, "the media are often a venue where cultural violence is created," (Bratić, 2008, p. 492) as they generate a symbolic environment and are capable of cultivating thoughts and attitudes in their audience that can lead to changes in behavior. While the mass media are never the sole source of social change, the "effects of the media are neither minimal nor negligible." Therefore, according to Bratić, "if the symbolic environment is impacted by the messages of peaceoriented media, such media environment can be conducive to the cultural transformation of violence" (Bratić, 2008, p. 493).

Because the meaning of peace media here is limited to mass media such as radio, television and newspapers, a particular difficulty presents itself: how can a mass medium that intends to accomplish certain outcomes-even if these are peaceful outcomesavoid being a propaganda medium? And is there such a thing as a pro-peace propaganda, or are peace and propaganda incompatible? What would the peace thus promoted look like? These questions are akin to the problems studied by the propaganda theorists of the 1920s. George Creel (1972), Walter Lippman (1922) and Harold Lasswell (1927) are among a generation of writers who, influenced by the experience of World War I (WWI), took up the study of mass media effects, trying to understand what kind of processes make propaganda effective. Although propaganda theory, as well as its surviving elements in public relations theory (Bernays, 1923, 1952), has attracted much criticism for reducing mass media audiences to a "bewildered herd" in need of control (Chomsky, 2002, p. 6, citing Lippmann's famous phrase), there was widespread conviction that propaganda could also be of a benevolent, pro-democratic kind. This belief was particularly convincing when pro-democratic and anti-German propaganda seemed the same, as in the work of the US Committee on Public Information, headed by George Creel. Bratić takes up Creel's idea of "employing all media of appeal" in pursuit of a cause and argues for peace media to be understood as part of a "peace relations agenda," of a "joint and integrated set of measures involving more than a single media channel or technique" (Bratić, 2008, p. 501). As is known, the US propaganda theorist found one of their main critics in John Dewey, who refused to "accept the need of a technocracy that would use scientific methods to protect people from themselves" and instead insisted that public education would be the most effective means of defending democracy against totalitarianism (Baran \& Davis, 2012, p. 86). According to Dewey, "democracy was less about information than conversation," (Alterman, cited in Baran \& Davis, 2012, p. 87) and such an education cannot proceed by creating a class of experts in control of information. Drewey may have seen in George Creel's propaganda strategy to bring Germany to surrender in WWI-known as the Fourteen Points of Wilson-a powerful indication of a collusion that may exists between propaganda and totalitarianism (Bateson, 1972, pp. 477-495).

Are there ways in which technological media can support peacebuilding outside of a model of benign propaganda? In order to answer this question, I will look at conceptual differences between conflict resolution and conflict transformation and their relationship to peacebuilding in the next section.

\section{Conflict Resolution, Conflict Transformation and Peacebuilding}

As a distinct conflict management technique, conflict transformation appeared in the 1990s (Lederach, 1995). Lederach describes conflict transformation as "to envision and respond to the ebb and flow of social conflict as life-giving opportunities for creating constructive change processes that reduce violence, increase justice in direct interaction and social structures, and respond to real-life problems in human relationships" (Lederach, cited in Dietrich, 2013, p. 7).

The utility of the concept has been a matter of controversy. Critics have argued that conflict transformation merely refers to the "deepest level of the conflict resolution tradition" (Ramsbotham, Woodhouse, \& Miall, 2011, p. 9), or that conflict transformation emerged as a response to a growing misuse of the term conflict resolution, being wrongly applied to many processes involving open violence (Mitchell, 2003). According to such criticism, conflict transformation would be synonymous to conflict resolution well done.

Mitchell (2003) makes a systematic attempt at 
identifying any substantive differences between the two concepts. He refers to Galtung's statement that "conflicts are generally not solved" because there is a conflict energy that does not disappear with the assumed resolution of the conflict, but rather "attaches itself to one or more conflicts, possibly also the old one" (Galtung, cited in Mitchell, 2003).

Although understanding the difference between conflict transformation and conflict resolution mainly as variations of emphasis, Mitchell does attribute to conflict transformation a focus on long-term healing:

"Resolution has a tendency to concentrate upon the immediate and the shorter term, its advocates arguing that dealing with the issues and the deeper interests producing a current situation of intractable conflict is enough of a problem in itself. Transformation has deliberately included 'the aftermath' in its focus, purposefully building in approaches and processes that deal with conflict 'residues'traumas, fears, hurts and hatreds - which, even if one major conflict has been resolved, will remain to poison futures and ensure that later conflicts will be prosecuted in a spirit of intransigence, if not revenge" (Mitchell, 2003).

Conflict transformation, then, would see its work continue in post-conflict scenarios and include techniques and activities that are typically part of peacebuilding.

Dietrich (2013) proposes a more clear-cut distinction between conflict transformation and conflict resolution. He understands conflict resolution as a "modernist concepts of international relations" and as having been "deconstructed by postmodern philosophy" ( $p$. 7). Accordingly, conflict resolution is about removing or ending a conflict, following the dramaturgy of a crime novel. The story ends with the resolved conflict. As in the crime story, "any re-traumatization of victims, of the victim's family, or of erroneous suspects at the hand of investigators and court officials is subordinate to the just and correct resolution. Life after the resolution is of no interest" (Dietrich, 2013, p. 8). Unlike conflict resolution, which rests on the idea of overcoming and ending a conflict, conflict transformation, as understood by Dietrich, is a process described by the German word verwinden, originating in Heidegger's problematizing of metaphysics that gave rise to a reorientation of continental philosophy in poststructuralism and postmodernism. Verwindung is usually translated as "twisting" in English (Sützl, 2007) and can be likened to recovering from the disease, which is different from the disappearance of the disease. The "twisting" of a conflict initiates a process of maturing, of discovering and of developing new choices, a process that "changes human relationships and personal consciousness" and is entirely different from any formulaic problem solving. This approach to conflict is transfor- mative of social systems and of individuals. Dietrich's understanding of conflict transformation is based on energy locked in the epicenter of the conflict, released in conflict work and used for transformation.

Conflict transformation thus goes beyond a movement on the surface of a conflict that Lederach calls an "episode" in which "physical violence is suppressed, the extremes of structural violence mitigated, and a new narrative form, a compromise, the famous winwin solution, is found" (Dietrich, 2013, p. 8). As a result, the energy of the conflict is not transformed, it is merely shifted elsewhere. Using a musicological term, Dietrich calls this a "conflict transposition." The score (or conflict) remains the same, but being rendered in a different pitch, the mood changes: "A melody is perceived differently and gives rise to different feelings when rendered in A major as opposed to F major. It is precisely this, and nothing more, that is done in conflict transposition" (p. 8). Conflict transformation, by contrast, claims to alter the dissonant melody itself, "utilizing its urgent energy creatively in order to form a new harmony based on what exists" (p. 9).

As to the use of media, the attention given to psychological and symbolic aspects in conflict transformation suggest limitations of peace media understood as mass media, and opens up the question of a type of medium.

\section{Neutrality and Permeability}

This becomes even clearer when we consider how those who advocate for conflict transformation as an entirely different enterprise understand the space of mediation, in the sense of the meson as discussed above. While the resolutional school has typically viewed the intermediary as a conflict broker, who, while required to have an appropriate understanding of the "culture and social structures in which the adversaries are embedded," (Mitchell, 2003) is not part of the same structure. The intermediary is an intermediary by virtue of his/her neutrality and separation from the conflict itself.

By contrast, conflict transformation theorists tend to acknowledge that mediators bring their own baggage to a conflict and are therefore never neutral. Dietrich (2013) asserts that "what many think to be objectivity and neutrality is nothing other than the assessment of a particular situation by a third party which, by virtue of the assessment, becomes an interested party and cannot be a neutral element" (p. 11). Neutrality, in his view, is a principle firmly rooted in a western and modernist world view that has left peace politics in a dilemma between idealist and realist assumptions (Dietrich, 2012). Dietrich does argue for "impartiality," as a "subjective attempt to avoid unilateral, thoughtless, and explicit expressions of partiality," (Dietrich, 2013, p. 12) but otherwise, precisely because of the impossibility of neutrality, the emphasis is 
on the mediator needing to be neither neutral nor distanced, but "permeable" (Dietrich, 2013, p. 210). This means that the mediator shares with the conflict parties what he/she brings to the conflict (values, emotions, desires, intentions, own traumas, etc.) in order to be able to facilitate a transformation process that will, inevitably, also be the transformation process of the mediator. The mediator forms part of the conflict scenario as a complete person, and is no longer seen as an expert with an advance in knowledge vis-à-vis the conflict parties.

From a media-theoretical point of view, this implies a shift in the view of the in-between space, of the medium of communication in conflict transformation. It marks a shift from a prescriptive to an elicitive approach to conflict that mirrors the transition from old to new media. Below I will examine some of the differences claimed to exist between conflict resolution and elicitive conflict transformation in order to arrive at conclusions regarding the latter's view of the space between conflict parties. This will help develop our understanding of the media that can exist in that space.

\section{Prescriptive and Elicitive Conflict Transformation}

The concept of elicitive conflict transformation originates in Lederach's 1995 book Preparing for Peace (Lederach, 1995). Here, Lederach responds to a concern about understanding and honoring the cultural dimension of conflict, and develop trainings for conflict transformation that no longer pretend to offer a how-to-dopackage created by conflict experts. Instead of transferring outside knowledge-knowledge developed in a different setting, expert knowledge disconnected from the cultural vernacular - the transformation of a conflict needs to put to use the resources, including the cultural forms, available within the conflict setting itself. In a nutshell, Lederach makes a case for a conflict transformation training that no longer proceeds in a prescriptive manner, transferring "conflict resolution technology from one setting to another," and which instead "builds from the cultural resources in a given setting" (Lederach, 1995, p. 7). Whereas in the prescriptive model the "trainer's knowledge is the key resource to be emulated by the participants," (p. 51) the conflict can be resolved precisely because culture is left out, the elicitive model uses culture as a resource in transforming the conflict (see Table 1).

Going beyond training requirements, Dietrich (2013) develops a theoretical grounding for the elicitive approach that follows from a far-reaching critique of concepts of peace in history and culture (Dietrich, 2012). He juxtaposes two historically large families of peace that have existed in the world. Energetic peace assumes human existence to be "embedded in the AllOneness of being" (Dietrich, 2012, p. 273) where consequently peace is a harmonious interplay of cosmic, natural and societal energies. The other family of interpretations is what he calls "moral peace" (peace as identical with justice), where a split between the eternal divine peace and the temporal peace of mundane existence emerges and peace is understood as a vectorial projection into a future. "Modern" and "postmodern" interpretations of peace have drawn on these foundations each in their own way. Modern images of peace are "based on a mechanistic understanding of the world that evicts God and supposes reason in his place," while postmodern ones doubt the existence of an ultimate Truth and declare God to be dead. In postmodernism, the rationality of the modern spirit unites with relationality. "Truth, security and justice are recognized as constructs and peace thus becomes multiform and in need of definition within each context" (Dietrich, 2012, p. 274). Eventually, he proposes a novel and pluralistic concept: the "trans-rational peaces" (Dietrich, 2011, pp. 3-23, 2012, pp. 210-260), introducing a plural to a noun that dictionaries list only in the singular-itself a consequence of moral and modern interpretation of peace. Significantly, the trans-rational concept of peace "[enlarges] the ethical and aesthetic moment of existence beyond the limits of the modern persona and into transpersonality and thereby gains the energetic without abandoning the rational" (p. 274).

Table 1. Types of conflict transformation (Source: Lederach, 1995, p. 65).

\begin{tabular}{|c|c|}
\hline Prescriptive & Elicitive \\
\hline Training as transfer & $\begin{array}{l}\text { Training as discovery and } \\
\text { creation }\end{array}$ \\
\hline $\begin{array}{l}\text { Training as content } \\
\text { oriented: Master } \\
\text { approach and technique }\end{array}$ & $\begin{array}{l}\text { Training as process } \\
\text { oriented: participate in } \\
\text { model creation }\end{array}$ \\
\hline $\begin{array}{l}\text { Empowerment as } \\
\text { learning new ways and } \\
\text { strategies for facing } \\
\text { conflict }\end{array}$ & $\begin{array}{l}\text { Empowerment as } \\
\text { validating and building } \\
\text { from context }\end{array}$ \\
\hline $\begin{array}{l}\text { Trainer as expert, model, } \\
\text { and facilitator }\end{array}$ & $\begin{array}{l}\text { Trainer as catalyst and } \\
\text { facilitator }\end{array}$ \\
\hline Culture as technique & $\begin{array}{l}\text { Culture as foundation } \\
\text { and seedbed }\end{array}$ \\
\hline
\end{tabular}

In order to understand the media-theoretical quality of Dietrich's approach, it will be helpful to look at an important theoretical source for Dietrich's elicitive theory: the humanistic psychology movement. Emerging from the differences that a new generation of psychologists had with Sigmund Freud in the middle of the $20^{\text {th }}$ century, this movement distanced itself from the psychoanalytic focus on illness and sought instead to use psychological knowledge to release the potentials for growth in human beings and their communities. Writers such as Abraham Maslow, gestalt therapists Laura and Fritz Perls and Paul Goodman, psychodrama founder Jacob Levy Moreno, family therapist Virginia 
Satir, client-centered therapist Carl Rogers, communication scholar Gregory Bateson and transpersonal psychologist Stanislaf Groff were all concerned with the relationships that exist between the inner conflicts and potentials of a person, and the conflicts and potentials in society and politics - the ways in which the intrapersonal is affected by, and in turn affects, the interpersonal. The tools and methods of elicitive conflict resolution as suggested by Dietrich encompass all dimensions and layers of human existence, from the persona to the sexual, socio-emotional, intellectual and spiritual.

This "twisting" of the linear structures and of central categories, the fluidity of boundaries and the understanding of the self as communication is at the basis of ECT. How is this distinction relevant to conceptualizing elicitive peace media? I will try to answer this question in the following section.

\section{Prescriptive and Elicitive Peace Media}

Propaganda as a modality of mass communication is prescriptive by definition: it cannot but project certain social realities or values as desirable, promote certain attitudes and behaviors, or seek to influence the beliefs of an audience. Although associated with 1930s totalitarian ideologies, mass communication theorists such as Lasswell and Lippmann argued that a democratic polity needs its own kind of propaganda that will protect democracy against the danger of totalitarianism. Integrated with other social institutions, such propagandabased of peace media have been shown to support buiIding peace efforts following a violent conflict (Bratić, $2005,2008)$. Indeed, Lasswell thought of his propaganda theory of mass communication as a remedy against conflict. Influenced by Freudian thinking, he considered the inevitable political conflict arising in pluralist societies as "inherently pathological," and it was the responsibility of social researchers to find ways to "obviate conflict." Public discourse was to be replaced by democratic propaganda (Baran \& Davis, 2012, p. 83).

While these propaganda theories were evolving in the 1920s and 1930s and were fuelled by the appearance of Nazi propaganda in Europe, Bertolt Brecht developed his own critique of propaganda in his radio theory: he wanted the listeners of this mass medium to be able to engage in a conversation with one another, rather than just listening to programs they had no influence upon. Radio, he famously argued, should be transformed from a "distribution apparatus" to a "communication apparatus" if it is to have consequences (Brecht, 2000, pp. 41-46). The audience was not only to be instructed but should itself instruct (p. 43). Before the Nazis destroyed media freedom and set up their own unparalleled propaganda machinery after 1933, socialist organizations did in fact offer radio workshops for workers with the goal of turning radio into a participative, progressive medium (Brunner-
Szabo, 1989). Brecht's contribution to a more comprehensive theory of radio may have been stifled by his own skepticism vis-à-vis the technological media in general and his reliance on stage drama. It was only HansMagnus Enzensberger who returned to Brecht's demand in his 1970 Constituents of a Theory of Media, polemically demanding that the left finally enter the new media age and, in doing so, embrace a more unpredictable, disorderly model of emancipation (Enzensberger, 1970). His remedy against manipulation and propaganda was that everyone gets access to communication media. Writing well before the popularization of computers, his extensive list of new media includes "time-sharing computers, data banks, composing and learning machines, video-phones, laser techniques," in a striking anticipation of a similar conversation that set in once computers and the internet became available to larger audiences in the 1990s. New media activism (Lievrouw, 2011), hacktivism (Samuel, 2004), electronic civil disobedience (Critical Art Ensemble, 1996), the tactical media movement (Garcia \& Lovink, 1997; Kluitenberg, 2011) and Indymedia are some examples from this period that stood for new ways of putting new media towards an emancipatory use, generally motivated by a desire for a more just and open information society and by lending everyone a voice.

Drawing on artistic as well technological resources, these media activist movements sought to level the difference between author, audience and producer. Formed in the Web 1.0 age, many of them did not survive the spread of Web 2.0 technologies, although the hacking swarm Anonymous and Wikileaks would represent examples of a continuation of this movement in the present.

While some of this media activism did not go beyond being subversive, disturbing dominant discourses and interfering with media dispositives - and in as much as this was the case contributed to a larger critique of violence-there are also examples of using the computers and the internet to promote peace ideas and activism (Gray, 2005).

In former Yugoslavia, the ZaMir network was an early example of a civil-society peace-oriented computer network. Supported by anti-war groups in the various Yugoslav republics, it proofed capable of bypassing government-imposed curbs on communication during demise of the Yugoslav state at the beginning of the 1990s, and of continuing a conversation about peaceful alternatives amidst the nationalist and militaristic propaganda. In the US, PeaceNet was a member organization of the Association for Progressive Communication (APC), a computer network founded in 1990 providing online communication resources to peace activist and organizations, and pioneering the use of the internet for social movements (Noronha \& Higgs, 2010).

The need both Brecht and Enzensberger expressed for media serving communication rather than distribu- 
tion is echoed in these uses of the new media, marking a shift away from mass communication in the classical sense. The normative thinking exemplified by Brecht and Enzensberger, on the other hand, would seek to promote the public discourse by breaking the one-tomany structure of mass communication and envisioning a many-to-many model of communication by the masses instead. Rather than looking for ways to obviate conflict, conflict is seen as inevitable and even desirable in order to advance to a more egalitarian society.

Does the idea of distributed communication media that underlies these ideals of emancipatory media use contain clues as to the role of technological media in elicitive conflict transformation? The idea of emancipation connected to conflict transformation may be rather different from the European socialist thought inscribed into these normative theories. In its revolutionary form, emancipatory politics has resorted to violent conflict, and on the other hand, processes of elicitive conflict transformation may differ from western notions of emancipation. Even Enzensberger is not entirely free from a propagandistic sensibility when he speaks of "democratic manipulation," reminding readers that "there is no unmanipulated writing, filming, or broadcasting," the question being not "whether the media are manipulated, but who manipulates them." Enzensberger envisions manipulation as a distributed activity that makes everyone a manipulator, leading to a "selfregulating learning process which is made possible by the electronic media" (Enzensberger, 1970, p. 20).

\section{Cybernetics, Mediality, and Medium}

What Brecht's and Enzensberger normative theory proposes is, at closer inspection, a cybernetic idea: the idea of self-regulation that replaces central control. Gregory Bateson, a psychologist and a founding figure of cybernetics, is cited by Dietrich as one of the precursors ECT (Dietrich, 2013, pp. 28-29). Bateson's is a systemic view thae is primarily transformative; that is, it detaches itself from the ideal of a revolutionary subject that still underlies Brecht's and Enzensberger's thinking, and whose celebration in leftist social theory may have reached its culmination in the writings of JeanPaul Sartre. To Bateson, the self is a result of communication, and communication is therefore not something that an individual with a pre-existing sense of self does in an instrumental fashion: rather, it is "only through communication that one's reality and sense of self [could] be maintained." (p. 28) Therefore, all communication within and without the person must be connected through feedback cycles. On this basis, conflict is inevitable, and was in fact considered as an essential part of life by Bateson, and any "obviation" of conflict is neither possible nor desirable. To Bateson, conflict was an integrative part of being human, an existential fact that concerns the entirety of human existence, i.e. body, mind and the relations to others. Dietrich offers a figure to illustrate Bateson's relevance to ECT (see Figure 1).

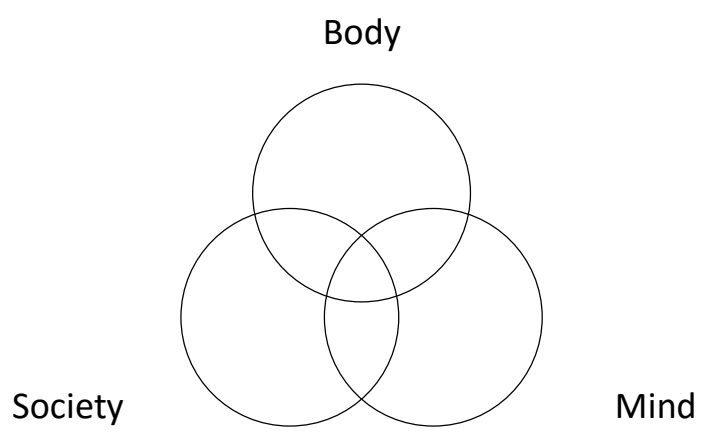

Figure 1. The systemic approach to peace after Bateson (Source: Dietrich, 2013, p. 28).

Conflict as an existential fact is also key in the thinking of Martin Buber, who Dietrich cites as another precursor of ECT. According to Buber, we are driven to choose between two conflicting basic attitudes: orienting (seeking security) and realizing (seeking change). As both of these attitudes aim for something desirable but are mutually exclusive, a permanent conflict between the two is inevitable. (Dietrich, 2013, p. 26). This existential conflict is present in any other form of conflict experienced by humans, and as a consequence, a conflict cannot be neutralized, but can only be transformed by seeking a balance between orienting and realizing.

We can ask the question of technological media in $E C T$, then in this way: does the systemic interconnectedness of layers of existence, of inner and outer experience, of people, communities, include or exclude technology? To answer this question, it will be useful to look at the common ground between humanistic psychology and cybernetics. Both disciplines emerged in the same historical context and pursued similar epistemic goals, influenced by systems theory. Therefore, system-theoretical concepts such as feedback cycle, boundary, interface, or environment are used in humanistic psychology as well as in cybernetics. Scholars such as Gregory Bateson, Norbert Wiener, Heinz von Foerster and Gregory Bateson were all concerned with how human and technological systems interact and evolve. Reviewing the historical evolution of cybernectics, Katherine Hayles reminds us that Gordon Pask, a founding figure of cybernetics who was also a humanistic psychologist, understood cybernetics as concerned "with information flows in all media, including biological, mechanical, and even cosmological systems" (Hayles, 2010, p. 146). Cybernetics opens a door towards understanding the mediatic dimension of human existence, the way in which humans function as media.

The human body as a medium can be traced back 
to the origins of culture (or it is the origin of culture): dance, theater, ritual performances and the like are long-standing ways of what Nietzsche in the Birth of the Tragedy referred to as the "original dramatic phenomenon: to see oneself transformed before one's eyes and now to act as if one really had entered another body, another character" (Nietzsche, 2000, p. 50). $20^{\text {th }}$ century psychology, philosophy and anthropology made an increasingly strong case against the possibility of static, or even stable, experience of the self, as well as the undivided, closed-in understanding of the subject that has marked the modern era. Being human means being a human medium, always entering or exiting different states, being fluid rather than static. Without this media-nature of human beings, it is impossible to imagine mediating a conflict.

It is therefore only consequential that the methods of ECT proposed by Dietrich all draw on this medial dimension of being human: he groups them into breath-, voice-,and movement-oriented approaches, implicitly describing forms of human mediality. Techniques include "transformative theater work," "political constellations," the Japanese traditions of Butō and Aikido, breathing techniques, Ruth Cohn's theme-centered interaction and Marshall Rosenberg's non-violent communication. All of these techniques rely of humans to be fluid selves, to cross boundaries, to be their own media, and in being their own media, being able to mediate-a verb whose meaning then would be: transforming a conflict by virtue of being a medium, of "seeing oneself transformed."

Cybernetics has prepared an understanding of such a mediated and mediating sense of communicated and communicative self as crossing the boundary to the technological, viewing both human bodies and technological media as part of an information-processing system. From a cybernetic point of view, therefore, in as much as humans are considered as being inherently medial, they are always potentially technological media because the boundary between the two is constantly shifting as messages are communicated.

What this also means is that the medium as a category entirely separate from the human is at odds with the premises of ECT as theorized by Dietrich. As little as ECT can rely on a static self or an essential human nature, it can assume an insuperable division between biological and technological systems. In the 1980s and 1990s, the concept of the cyborg (for 'cybernetic organism') was key in a debate that sought to give a positive social meaning to this process of shaping the integration of the biological and the technological from a peace-oriented perspective, breaking the military's dominance in this field of research. Using a term coined by Manfred Clynes and Nathan Kline (Clynes \& Kline, 1960), Chris Hables Gray (2002) and Dona Haraway (2000) reminded us of the simple fact that everyone who has been vaccinated is a cyborg, because his or her body no longer functions according to biological principles alone. But vaccines are often the result of a profit-driven, boxed system of patented expert knowledge, dominated by a patriarchal culture and government secrecy. By breaking these boxes, cyborgization was understood as a possible part of a peaceoriented, progressive cultural movement that embraced technology rather than avoiding it. Cyborgization was theorized by these authors as a cybernetic transformation that would transform society by working across what we could call, borrowing a word from gestalt therapy, the biology-technology contact boundary.

\section{Elicitive Conflict Transformation and the Social Web}

While ECT advocates work with forms of human mediality but seem to largely exclude non-human media, the very discipline that provides some of the main theoretical inputs for ECT, cybernetics, has developed a systemic way of thinking about communication that permeates the boundary between biological and technological processors of information. To not consider technological media as part of the communication processes on which ECT relies contradicts the very intentions of ECT. From a media-theoretical point of view, ECT inserts itself into evolution from centralized to de-centralized, from mass media to distributed networks, from one-to-many to many-to-many communication that allows it to elicit knowledge by pooling resources offered by users. However, this in itself does not necessarily make those media more conducive to building peace, nor does the possibility of propagandistic manipulation disappear, as Enzensberger hoped, when everyone becomes a manipulator.

Thus, when we look at current Web 2.0 media, we might at first look at a realization of the demands made by three generations of media activists, from Brecht in the 1920 s to the alternative, social movement and activist media of the present: every receiver is also a sender, access to communication is easy, distributed and flexible networks replace powerful mass media. Indeed, we already seem to inhabit a media world where people "do no evil" (Google), and are engaged in constant process of turning strangers into "friends" (Facebook). Social media seem to at least define themselves as peace media of sorts.

But while the propagandists seem to have disappeared, and manipulation now is in everyone's hand, propaganda itself has not. When something is "trending" on Twitter, we might be looking at a social-media revenant of what the Institute for Propaganda Analysis in 1939 described as the "bandwagon:" "Everyone, at least all of us-is doing it" (Institute for Propaganda Analysis, 1979, p. 24). Ranking search displays by popularity-the most important component of Google's page rank algorithm-mirrors the "plain folks" technique identified by the Institute: an idea is good because it is 
"of the people, the plain folks" (p. 24), and it would probably take little effort to identify social web equivalents of all the other propaganda techniques. The difference is that due to the distributed structure and the accessibility of the social web, these propagandistic elements appear to be the outcome of a 'democratic' process. Moreover, when looking at the peacebuilding potential of the social web, it must be remembered that social media have not just been hailed as the engines of positive social change, but simultaneously criticized as master tools of profit generation in an age of info-liberalism (Banning, 2016), applying a business model that supplies advertisers with user attention and user information.

How can social media can play this double role of being effective tools for social movements, and thus peacebuilding, while at the same time generating subjectivities that fall in line with the demands of the neoliberal model of info-capitalism? As far as the social web is concerned, peacebuilding and info-capitalism want the same thing: the growth in user numbers of Facebook, for example, increases the utility of the network for the individual user, providing social movements with an efficient communication channel and a means of mobilizing support. "Peace" and corporate profits then are become indistinguishable. Everyone is involved in "making the world a better place," or in "making a difference," to quote two popular items of a neoliberal vocabulary that makes peace redundant.

The neoliberal agenda, driving the political out of politics becomes indistinguishable from the peace that follows the win-win resolution of conflicts. What separates peace activists from shoppers, or peacebuilding NGOs from investment banks, can no longer be meaningfully expressed in environments where everyone is a friend. In fact, there is no need to express differences of a political nature at all, as Laswell's idea of obviating conflict, intended to avoid the violence of political extremism in the 1930s, seems to have come to a surprising and successful conclusion.

Contemporary social media represent a symbolic environment of relentless positivity. Byung-Chul Han $(2010,2013)$ has argued that the "digital swarm" and its sphere of boundless positivity and tireless promotional discourses creates its own violence: making it impossible to work with distinctions of negativity that are necessary to make a conversation politically meaningful, drying out the very intellectual and symbolic resources that are needed to effectively criticize violence in the first place. As a consequence, the media dominating the social web are creating a communication environment without an outside, what could be called "total communication." And in total communication, for lack of negative, limiting criteria, conflict can never be perceived as a political conflict because it can never be communicated in terms that allow the construction of a distinctly political meaning.
But just like ECT seeks to leave behind the idea that there should be a society or politics without conflict, any new medium that is to be a peace medium rather than an extension of liberalism into info-liberalism or neoliberalism, would need to make a symbolic repertoire available that allows negativity and is capable of communicating it.

I would characterize the social web therefore not as the peace medium of ECT but as an assemblage of neoliberal media that have succeeded in obviating conflict by generating an insistent positivity within which a potential political conflict exists only as a symbolic or economic exchange transaction that can only take place because it will immediately result in a reconciliation. In an anti-liberal, authoritarian setting, this distinction between a medium that helps build peace, and a neoliberal medium that is, after all, still liberal, might not be immediately apparent or even significant, and this is one way of understanding the undue importance assigned to social media in popular uprisings of recent years.

But as Byung-Chul Han $(2011,2013)$ has also pointed out, this sphere of boundless positivity and relentless promotion creates its own violence: making it impossible to work with distinctions of negativity that are necessary to make a conversation politically meaningful, drying out the very intellectual and symbolic resources that are needed to effectively criticize violence in the first place. As a consequence, the dominant social media have no way of limiting themselves, they create what could be called total communication. The transformation of conflict, in ECT inseparable from embracing conflict as an existential fact, is not possible there, while the win-win structure of these media is remains a solution that never knew a conflict.

\section{Conclusion}

Against the above reasoning, the purpose of new peace media in elicitive conflict transformation seems paradoxical: they must be able to communicate a kind of negativity that makes it possible to speak of losses in order to help find ways to reduce violence in a way that is meaningful and can be expressed in political terms.

This is where we must return to Schmitt (2007) (whose theory of irreconcilable opposition makes him an unlikely reference for either conflict resolution or conflict transformation). However, his critique of liberalism as a de-politicizing power seems is proving difficult to dismiss. Chantal Mouffe (2013) critically engages in with Schmitt's position in her own critique of the dominant model of liberal democracy, and when looking for the meaning technological media could have in $E C T$, this may be helpful starting point. According to Mouffe, "liberalism is unable to adequately envisage the pluralistic nature of the social world, with the conflicts that pluralism entails" (Mouffe, 2013, p. 3). But moving these conflicts from a struggle between ene- 
mies to a struggle between adversaries is at the heart of her agonistic model of radical democracy. From this perspective, media that offer themselves as a resource for a politically meaningful yet non-violent discourse might therefore be potential new peace media. In keeping with the fundamental ideas of ECT, such media will look different in each specific conflict.

\section{Acknowledgments}

Thanks to Samantha Ventrella for proofreading this manuscript.

\section{Conflict of Interests}

The author declares no conflict of interests.

\section{References}

Banning, M. (2016). Sharing entanglements. Web 2.0, info-liberalism, and Digital Sharing. Information, Communication and Society, forthcoming.

Baran, S. J., \& Davis, D. K. (2012). Mass Communication Theory: Foundations, Ferment, and Future (6th ed.). Boston, MA: Wadsworth Publishing Co.

Bernays, E. (1923). Crystallizing Public Opinion. New York: Boni and Liveright.

Bernays, E. (1952). Public Relations. Norman: University of Oklahoma Press.

Bratić, V. (2005). In search of peace media: Examining the role of media in peace developments of the postCold War conflicts (Doctoral Dissertation). Retrieved from OhioLINK Electronic Theses \& Dissertations Center.

Bratić, V. (2008). Examining peace-oriented media in areas of violent conflict. International Communication Gazette, 70(6), 487-503.

Brecht, B. (2000). Brecht on film and radio. London: Methuen Drama.

Brunner-Szabo, E. (1989). Medien in Widerstand. Vom Arbeiter-Radiobund in der 1. Republik bis zu den freien Radios und Piratensendern, oder Möglichkeiten eines demokratischen Gebrauchs von Massenmedien (Doctoral Dissertation). University of Vienna, Austria.

Burton, J. (2015). Conflict and communication. In T. Woodhouse, H. Miall, O. Ramsbotham, \& C. Mitchell (Eds.), The contemporary conflict resolution reader (pp. 28-32). Cambridge, UK: Polity Press.

Chomsky, N. (2002). Media Control (2nd ed.). New York: Seven Stories Press.

Clynes, M., \& Kline, N. (1960). Cyborgs and space. Astronautics, 9, 27-76. Retrieved from http://web.mit. edu/digitalapollo/Documents/Chapter1/cyborgs.pdf

Cox, G., \& Sützl, W. (Eds.). (2009). Creating insecurity. Art and culture in the age of security. New York: Autonomedia.

Creel, G. (1972). How we advertised America. New York:
Arno Press.

Critical Art Ensemble. (1996). Electronic civil disobedience and other unpopular ideas. New York: Autonomedia.

Curle, A. (2015). In the middle. In T. Woodhouse, H. Miall, O. Ramsbotham, \& C. Mitchell (Eds.), The contemporary conflict resolution reader (pp. 259-262). Cambridge, UK: Polity Press.

Dietrich, W. (2011). Beyond the gates of Eden: Transrational peaces. In W. Dietrich (Ed.), The Palgrave international handbook of peace studies (pp. 3-23). Basingstoke: Palgrave MacMillan.

Dietrich, W. (2012). Interpretations of peace in history and culture. New York: Palgrave Macmillan.

Dietrich, W. (2013). Elicitive conflict transformation and the transrational shift in peace politics. Basingstoke: Palgrave MacMillan.

Dillon, M., \& Reid, J. (2000). Global governance, liberal peace, and complex emergency. Alternatives, 25(1), 117-143.

Dillon, M., \& Reid, J. (2009). The liberal way of war: Killing to make life live. London; New York: Routledge.

Enzensberger, H. M. (1970). Constituents of a theory of the media. New Left Review, (64), 13-36.

Eurich, C. (1995). Tödliche Signale. Die kriegerische Geschichte der Informationstechnik von der Antike bis zum Jahr 2000. Frankfurt: Luchterhand.

Evans, B. (2011). The liberal war thesis: Introducing the ten key principles of twenty-first-century biopolitical warfare. South Atlantic Quarterly, 110(3), 747-756.

Galtung, J. (1964). An editorial. Journal of Peace Research, 1(1), 1-4.

Galtung, J. (1990). Cultural violence. Journal of Peace Research, 27(3), 291-305.

Lovink, G., \& Garcia, D. (1997). The ABC of tactical media. Retrieved 2 December 2015, from http://www. nettime.org/Lists-Archives/nettime-I-9705/msg0009 6.html.

Gilboa, E. (2010). Media and conflict resolution: A framework for analysis. Marquette Law Review, 93(1), 87-111.

Gray, C. H. (2002). Cyborg citizen: Politics in the posthuman age. New York: Taylor \& Francis.

Gray, C. H. (2005). Peace, war, and computers. New York: Taylor \& Francis.

Haraway, D. (2000). A cyborg manifesto: Science, technology and socialist-feminism in the late twentieth century. In D. Bell \& B. M. Kennedy (Eds.), The cybercultures reader (pp. 291-324). London and New York: Routledge.

Han, B.-C. (2010). Müdigkeitsgesellschaft. Berlin: Matthes \& Seitz.

Han, B.-C. (2013). Im Schwarm. Ansichten des Digitalen (1st ed.). Berlin: Matthes \& Seitz.

Hayles, N. K. (2010). Cybernetics. In W. J. T. Mitchell \& M. B. N. Hansen (Eds.), Critical terms for media studies (pp. 145-156). Chicago: University of Chicago Press. 
Institute for Propaganda Analysis. (1979). The fine art of propaganda. San Francisco: International Society for General Sementics.

Keeble, R. L., Tulloch, J., \& Zollmann, F. (Eds.). (2010). Peace journalism, war and conflict resolution. New York, NY: Peter Lang Publishing.

Kluitenberg, E. (2011). Legacies of tactical media the tactics of occupation: From Tompkins Square to Tahrir. Amsterdam: Institute of Network Cultures.

Lasswell, H. D. (1927). Propaganda technique in the World War. New York: Knopf.

Lederach, J. P. (1995). Preparing for peace: Conflict transformation across cultures. Syracuse, NY: Syracuse University Press.

Lievrouw, L. A. (2011). Alternative and activist new media. Cambridge, UK: Blackwell Publishers.

Lippmann, W. (1922). Public opinion. New York: Macmillan.

Lynch, J., \& McGoldrick, A. (2005). Peace journalism. Stroud: Hawthorn.

Michtell, C. (2003). Beyond resolution: What does conflict transformation actually transform? Peace Research Abstracts, 40(2), 123-261.

Mouffe, C. (2013). Agonistics. Thinking the world politically. London: Verso.

Nietzsche, F. (2000). The birth of the tragedy. Oxford: Oxford University Press.

Noronha, F. \& Higgs, K. (2010). The internet is a "radically different" place because of APC. Retrieved from http://www.apc.org/en/node/10678

Ramsbotham, O., Woodhouse, T., \& Miall, H. (2011). Contemporary conflict resolution. The prevention, management and transformation of deadly conflicts.
( $3^{\text {rd }}$ ed.). Cambridge, UK: Polity Press.

Richmond, O. P. (2011). A post-liberal peace. Milton Park and New York: Routledge. 2011.

Saleem, N., \& Hanan, M. A. (2014). Media and conflict resolution: Toward building a relationship model. Journal of Political Studies, 21(1), 179-198.

Samuel, A. W. (2004). Hacktivism and the future of political participation (Doctoral Dissertation). Cambridge, MA. Retrieved from http://alexandrasamuel.com/ dissertation/pdfs

Schmitt, C. (2007). The concept of the political. Chicago: University of Chicago Press.

Snow, N. (2003). Information war: American propaganda, free speech and opinion control since 9/11. New York: Seven Stories.

Stocker, G., \& Schöpf, C. (Eds.). (1998). Ars Electronica 98: Infowar - information, power, war / Information, Macht, Krieg. Berlin: Springer Verlag.

Sützl, W. (2007). Emancipación o violencia. Pacifismo estético en Gianni Vattimo. Barcelona: Icaria.

Sützl, W. (2008). Die Rückkehr Heraklits. Zur politischen Poetik einer Kritik der Gewalt. In W. Sützl \& D. Wallnöfer (Eds.), Gewalt und Präzision. Krieg und Sicherheit in Zeiten des War on Terror (pp. 59-78). Vienna, Austria: Turia+Kant.

Sūtzl, W. (2009). Languages of surprise. Toward a political poetics of insecurity. In G. Cox \& W. Sützl (Eds.), Creating insecurity. Art and culture in the age of security (pp. 67-81). New York: Autonomedia.

Virlio, P. (1989). War and Cinema. The Logistics of Perception. New York: Verso.

Winthrop-Young, G. (2011). Kittler and the media. Cambridge: Polity Press.

\section{About the Author}



\section{Dr. Wolfgang Sützl}

Wolfgang Suetzl is a philosopher, media theorist, and linguist. He is currently a Visiting Assistant Professor at Ohio University' School of Media Arts and Studies, and previously researched media activism at the University of Innsbruck, Austria. His research interests include media and social change, digital sharing, mass communication theory, media history, and media aesthetics. 